\title{
REVIEW
}

\section{The bases of the inflammatory acute abdomen}

\author{
Kubikova E, El Falougy H, Selmeciova P \\ Department of Anatomy, Faculty of Medicine, Comenius University, Bratislava, Slovakia. \\ eliska.kubikova@fmed.uniba.sk
}

\begin{abstract}
Vermiform appendix is an anatomical structure, which due to its topographical relations usually causes many complications, especially in inflammation such as appendicitis. One of the manifestations of the inflammatory processes is pain, which may have different location. It could be probably a result of the neuron stimulation. The nerve formation and distribution of the vermiform appendix is still unknown in fine details and is a subject of further studies (Fig. 8, Ref.12). Full Text in PDF www.elis.sk.

Key words: anatomy, vermiform appendix, appendicitis, pain, innervation.
\end{abstract}

Vermiform appendix, a seemingly unremarkable anatomical structure, usually causes many complications. These arise from the topographical relationship to surrounding structures in the abdomen. Due to its position and related disorders, concerning the vermiform appendix itself and the surrounding structures, the organ remains a structure of multidisciplinary interest. The senior physician does not meet with any other disorders as frequently as with appendix diseases, which usually causes acute abdomen. They are always unpredictable, often life-threatening acute diseases.

The consequences of hesitation, late diagnosis or misdiagnosis are severe not only for the patient, but often also to a surgeon. In no other medical field so many complains and serious allegations at medical procedure exist as in the acute abdomen.

According to these reasons, the vermiform appendix is an anatomical structure of considerable significance.

\section{Anatomy of the vermiform appendix}

Vermiform appendix is a blind, 5-10 cm long, tip of caecum. It arises from its posteromedial surface, about $2 \mathrm{~cm}$ from the ileal orifice, where is an inlet of the terminal part of the small intestine into the caecum. Vermiform appendix has an external diameter of about 3-8 $\mathrm{mm}$, internal diameter about $1-3 \mathrm{~mm}$. During the whole life, the largest diameter is found in newborns and young children (Dhillon et al, 1992). In middle age, due to vermiform appendix obliteration, the diameter is arrowed. In seniority, the organ obliteration is a consequence of the lymphatic tissue reduction. To the appendix, a peritoneal duplication - the mesoappendix is attached, which allows considerable appendix mobility. In the mesoappendix blood, lymph vessels and nerve plexuses are found.

The most common cause of the acute abdomen is usually an inflammation of the appendix, appendicitis. Its behavior is

Department of Anatomy, Faculty of Medicine, Comenius University, Bratislava, Slovakia

Address for correspondence: E. Kubikova, MD, PhD, Department of Anatomy, Faculty of Medicine, Comenius University, Spitalska 24, SK81372 Bratislava, Slovakia.

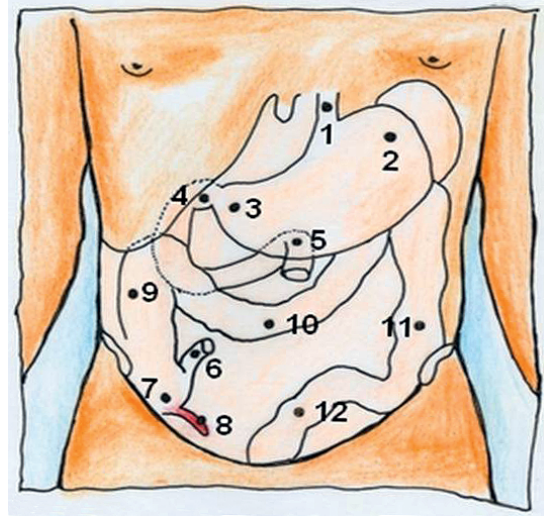

Fig. 1. The projection of organs to the anterior abdominal wall. 1. cardia ventriculi, 2 . fundus ventriculi, 3 . antrum pyloricum, 4 . duodenum, 5. flexura duodenojejunalis, 6. ileum, 7. caecum, 8. appendix vermiformis (positio pelvica), 9. colon ascendens, 10. colon transversum, 11. colon descendens, 12 . colon sigmoideum.

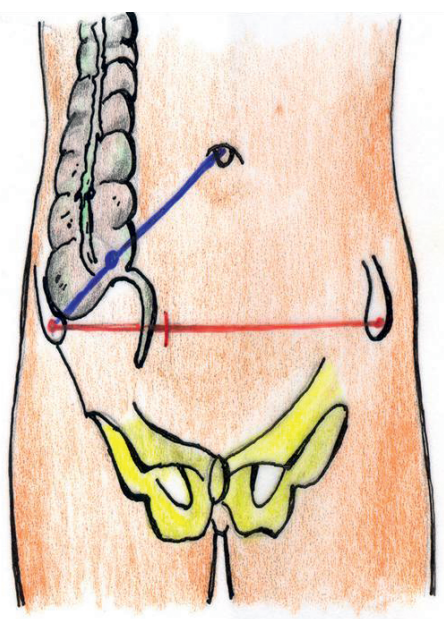

Fig. 2. The projection points of vermiform appendix on the anterior abdominal wall. Blue line-Mc Burney's point, red line-Lanza's point. 


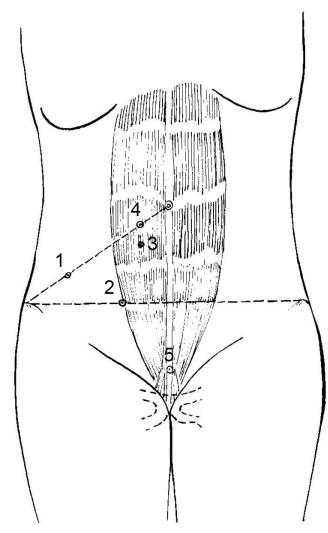

Fig. 3. Other pain points of the vermiform appendix. 1. Mc Burney's point, 2. Sonnenburg's point, 3. Walther's point, 4 . Moris' point, 5. suprapubic (Rastouil's) point.

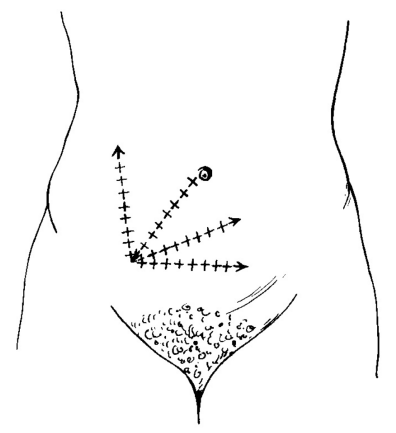

Fig. 4. Pain spreading during appendicitis.

capricious, almost uncanny with differences in adults and children. Therefore, this inflammation affects humans at all life stages. In some cases, appendicitis is presented abruptly, sometimes with a clear picture, after short obscure onset with later clear symptoms or as unnoticeable syndrome. Apart from the appendicitis presentations, such as nausea and constipation or subfebrilities, the most classical symptom is pain. The location of pain depends on the vermiform appendix projection to the anterior abdominal wall (Fig. 1).

\section{The projection points of the vermiform appendix}

Vermiform appendix is usually reflected in the Mc Burney's point, which presents its origin. The point is located at the junction of the anterior superior iliac spine with umbilicus (Monro's line), about $6 \mathrm{~cm}$ from the spine (Karim et al, 1990). On the boundary between the right and middle third of interspinous distance is presented the Lanza's point (Fig. 2). In addition to these classical projection points on the anterior abdominal wall (which differ at least), in literature are mentioned also others, identified as pain points. They gain this term according to pain spreading during the appendicitis. These points are named after the author (Jirasek, 1958, Cunningham, 1995). Sonnenburg's point is located at the crossing of interspinous line with the outer edge of the right rectus abdominis muscle. The appendix origin about $4 \mathrm{~cm}$ from navel is indicated by Morris' point, on the line joining the umbilicus to the

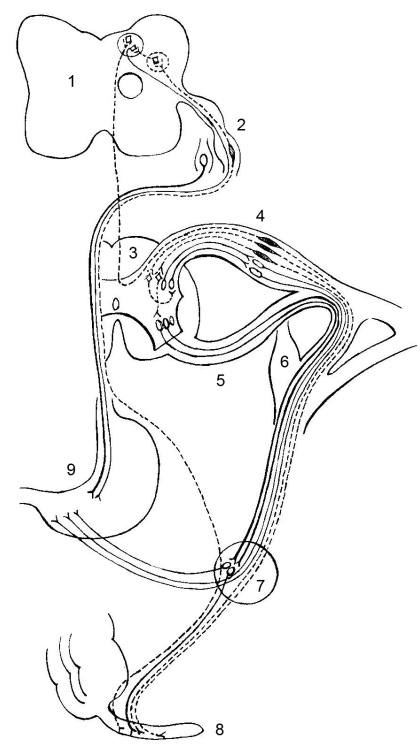

Fig. 5. The schema of the visceral reflex (vermiform appendix - stomach). Interrupted line - sensory fibers, thin line - parasympathetic fibers, thick line - sympathetic fibers. 1. medulla oblongata, nuclei nervi vagi, 2 . nervus vagus, 3 . medulla spinalis, 4 . radix anterior, 5. radix posterior, 6 . ganglion trunci sympathici, 7. ganglion coeliacus, 8. appendix vermiformis, 9 . gaster.
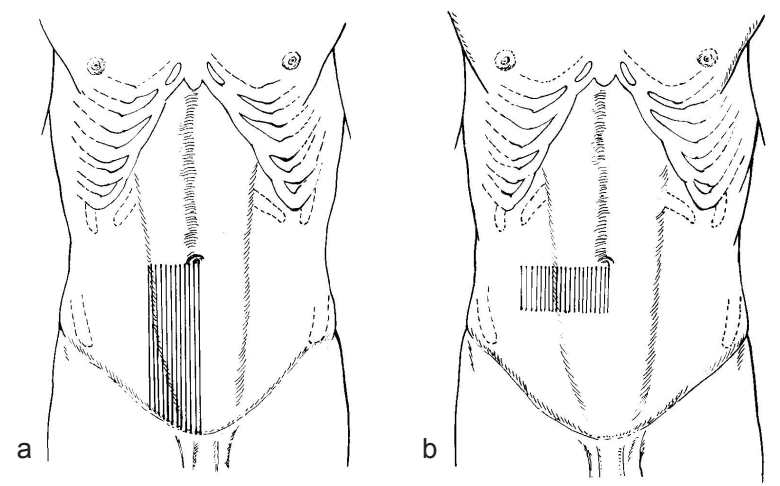

Fig. 6. The hyperalgesic region in acute appendicitis. a) central longitudinal type, b) central transverse type.

anterior superior iliac spine. Dorsally to the right rectus abdominis muscle, below the navel level and on the right side of the spine is the Walther's point. The Rastouil's point (suprapubic point) lies $2 \mathrm{~cm}$ above the pubic symphysis, on the line joining symphysis to the umbilicus (Fig. 3).

Beyond these points, the pain may localize to the centre of epigastrium, to the boundary between epigastric region and the anterior median line (Cope sign), or around the navel (Fowler sign). The pain explanation is quite complicated (Fig. 4). Some patients suffer a typical gastric pain (Methieu-Roux). Some patients may present with chest pain (Paqouet), pain under the right costal arch, in the right gluteal region along the sciatic nerve, in the rectum or in the right testis (Walther) and in urinary bladder (Jirasek, 1958). Pain may also occur on the left side (inverted intestinal rotation, vermiform appendix by its length is drawn toward the left iliac fossa). In every inflammation and therefore also in inflammation 

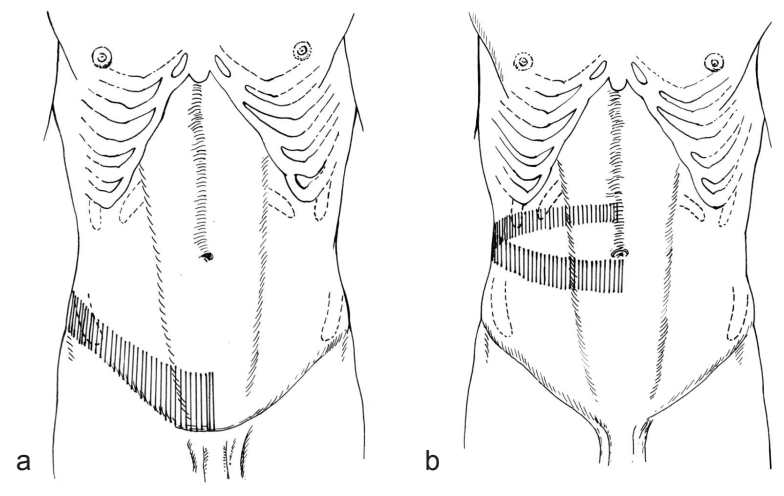

Fig. 7. The hyperalgesic region in acute appendicitis. a) ilioinguinal type, b) lateral transverse type.

of the inconspicuous anatomical structures, it is necessary to know the mechanism of pain. The spread of the pain and its intensity is related to the vermiform appendix innervation.

\section{The innervation of the vermiform appendix}

The autonomic innervation of the vermiform appendix is a part of the large intestine innervation. Parasympathetic nerve fibers originate from the vagus nerve. Sympathetic nerve fibers come from the thoracic and abdominal sympathetic ganglia through the splanchnic nerves (Mráz, 2003). By entering the appendicular wall, sympathetic fibers form plexuses accompanying blood vessels. The intrinsic nerve plexuses are formed in the appendix as in any other portions of the large intestine (Papadaki et al, 1983). The myenteric plexus lies between the circular and longitudinal muscle layers and the submucosal plexus is located in submucosa.

The autonomic nervous system transmits sensory fibers from the various layers of the vermiform appendix (Borovanský et al, 1988, Čihák, 1988). In the course of appendicitis, the pain indication varies. Is it pain from the abdominal wall or skin sensitivity? The surface sensitivity (skin hyperalgesia) could be explained on the base of visceral reflexes (Fig. 5) that would guarantee a constant position of the painful point. Here comes into the account a referred innervation, which is permanent and not affected by the intestine position or its origin. In determining the deep pain it is common that we can clearly identify appendicular pain. In case of perforation, the pain is significant and localized almost throughout the abdomen. The pain is accentuated in the right hypogastrium as a result of peritoneal irritation. There are several hyperalgetic sites (Fig. 6, 7, 8).

\section{Conclusion}

Despite a big progress in understanding the pathological process and the explanation of the caused of pain in the appendix region during appendicitis or during other pathological process in the abdomen, the neurons of vermiform appendix have to be considered (Williams and Myers 1994). In the period from 1982-1983 were described long known nerve plexus, which differs from the myenteric and submucosal plexuses. It is related to the subepithelial neurosecretory and ganglion cells. In the cells of this area, the

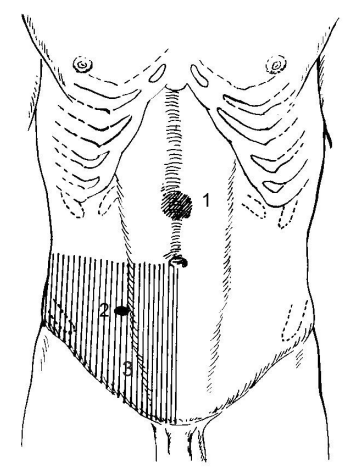

Fig. 8. Deep pain and surface sensitivity in acute appendicitis. 1. spreading pain, 2. deep pain in palpation, 3 . surface sensitivity.

presence of serotonin is not known. This leads to speculation that neurotransmitters may play a role in the non-inflammatory pain in the appendix (Höfler et al, 1983, Rode et al, 1983). Castorina (1993) also claims that neurogenous hyperplasia and the high density of epithelial neuroendocrine cells in non inflammed appendices suggest that neural mechanism and serotonin release from neurosecretory cells plays a role. This is implicated as the base of appendicular pain.

The work of this nature is so important and interesting in the light of the fact that a careful review of literature and vermiform appendix research may provide new perspectives in microanatomy and, as a consequence, new pain therapy in the appendix region.

\section{References}

Borovanský L et al. Sústavná anatómia človeka 1. Martin; Osveta, 1988: 524.

Cserni T et al. Atresia of the ileocecal junction with agenesis of the ileocecal valve and vermiform appendix: report of case. Surgery Today 2006; 36 (12): 1126-1128.

Cunningham's textbook of Anatomy. 12th Edition. Oxford, New York, Toronto; Oxford University Press, 1995: 1078.

Čihák R. Anatomie 2. Splanchnológia. Praha; Avicenum, Zdravotnícke nakladatelství, 1988: 74-75.

Dhillon AP, Rode J. Serotonin and its possible role in the painful inflammed appendix. Diagnostic - Histopathology 1983; 6: 239-242.

Dhillon AP. Age, site and distribution of subepithelial neurosecretory cells in the appendix. Pathology 1992; 24: 56-59.

Jirásek A. Náhle př́ihody břišní. Praha; Statní zdravotnickí nakladatelství, 1958: 628.

Höfler H, Kasper M, Heitz PU. The neuroendocrine system of normal human appendix, ileum and colon, and in neurogenic appendicopathy. Pathol Anat Histopathol 1983; 399 (2): 127-140.

Castorina S. Metasympathetic system and neuroendocrine elements of the human cecal appendix: immunohistochemical study. Boll Soc Ital Biol Sper 1993; 80 (4): 265-267.

Mráz P et al. Anatómia l'udského tela 2. Bratislava; SAP, 2006: 487.

Papadaki L et al. Fine structure of neuroendocrine complex in the mucose of the appendix. Gastroenterology 1983; 81: 190-197.

Rode J, Dhillon AP, Papadaki L. Serotonin - immunoreactive cells in the lamina propria, plexus of the appendix. Human Pathol 1983; 14: 464.

Received April 13, 2011. Accepted January 9, 2012. 